Available Online : https://proceeding.researchsynergypress.com/index.php/cset/index

RSF Conference Series: Engineering and Technology

ISSN 2809-6843 (Online) | 2809-6878 (Print)

Volume 1 Number 1 (2021): 603-608

\title{
A Measuring Satisfaction of Member UPN "Veteran" Yogyakarta Cooperative Whatsapp Group: Webqual 4.0 Model Adoption
}

\author{
Sriyonoํ, Oliver Samuel Simanjuntak², Riza Prapascatama Agusdin³, Sylvert Prian \\ Tahalea ${ }^{4}$ \\ ${ }^{1}$ Accounting Department, Universitas Pembangunan Nasional Veteran Yogyakarta, Indonesia \\ 2,3,4 Informatics Department, Universitas Pembangunan Nasional Veteran Yogyakarta, Indonesia
}

\begin{abstract}
This research adopted WebQual 4.0 to determine user satisfaction from members of the UPN "Veteran" Yogyakarta Whatsapp Group (WAG) cooperative. A total of 150 samples were obtained to be ready for analysis. Correlation and Regression Analysis were used to analyze. The analysis results show that the WAG members of the UPN "Veteran" Yogyakarta Cooperative are not satisfied with the quality of the information provided so far and the use of WAG as a medium for disseminating information. However, they are satisfied with the interactions carried out by the WAG admin in the group. In the future, it is hoped that the Yogyakarta "Veteran" UPN Cooperative can improve the way they provide information and pay attention to the quality of information before it is distributed to their WAG.
\end{abstract}

Keywords: User Satisfaction, WebQual 4.0, WhatsApp Group

\section{INTRODUCTION}

This is an open access article under the CC-BY-NC license

In recent decades, technology has changed the way people communicate. Communication becomes essential in life, where nearly $70 \%$ of the time is used to communicate (Mortensen, 2008). With today's technology, people can share very quickly, supported by existing internet networks everywhere, making communicating easier, especially with the discovery of instant messages that make it easier for everyone to communicate. Whatsapp is one of the instant messaging applications that allows communication between two people and groups. Today's group communication has dominated instant messaging applications, including WhatsApp, which has the Whatsapp Group feature or is often referred to as WAG. WAG allows users to communicate in groups in one communication room on the application. It has become ubiquitous to create WAG for informal purposes among friends or for more formal purposes among coworkers.

Cooperatives are one of the business fields in Indonesia whose purpose is to improve the standard of living of its members and the surrounding community, help create a just and prosperous society, and improve the economic order in Indonesia. UPN "Veteran" Yogyakarta has a cooperative whose aim is to enhance the welfare of employees within UPN "Veteran" Yogyakarta. Not only employees from UPN "Veterans" Yogyakarta can become members of the cooperative. People outside of it can be told that nonUPN "Veterans" Yogyakarta can become members of the cooperative. Because members are employees in their environment, the UPN "Veteran" Yogyakarta cooperative created a WAG to distribute information to all members, especially non-UPN "Veteran" Yogyakarta members. To make it easier for each member to find information without having to come to the cooperative office.

To provide good service to each member and provide updated information to its members, UPN "Veteran" Yogyakarta cooperative must continue to evaluate how the information distributes so that it can satisfy members on their WAG. The evaluation is carried out to find out whether the members of the WAG are satisfied or not. WebQual is a model for evaluating website quality. Webqual first appeared in 1998, and it has continued to experience several changes in dimensions and questions (Hermanto, Supangat and Mandita, 2017). The WebQual model has three essential elements to measure website quality: usability, information quality, and service interaction quality (Diana and Veronika, 2018) (Ngulum and Aries, 2020).

In this research, WebQual 4.0 was adopted to measure the satisfaction of WAG members of the UPN Yogyakarta "Veteran" Cooperative. The Webqual model is a development of the ServQual model, which 
Sriyono, Oliver Samuel Simanjuntak, Riza Prapascatama Agusdin, Sylvert Prian Tahalea

was previously used in measuring service quality. Different kinds of WAG have been analyzed for diverse objectives. For example, research conducted by (Rambe and Chipunza, 2013), WAG as collaborative media for students share various issues about the course, and (Johnston et al., 2015) research about WAG used for healthcare communication amongst $t h$ e surgical team. The purpose of this research is to determine whether the usability, quality of information, and quality of service interaction which are part of the WebQual 4.0 model, can affect user satisfaction of WAG member UPN "Veteran" Yogyakarta Cooperative.

\section{LITERATURE REVIEW}

\section{WEBQUAL 4.0}

The ServQual model is the basis for the establishment of WebQual, which is where ServQual develops into a model that can assess technology services, namely WebQual. WebQual is basically a method or technique for measuring the quality of a website based on end-user perceptions. WebQual has been created since 1998 and has sustained several iterations in the preparation of variables and indicators. The first version of the WebQual model (as we know as WebQual 1.0) was developed to measure the quality of school websites. The WebQual instrument was screened through an iterative improvement process using a trial questionnaire before being distributed to a larger population. The twenty-four questions were tested with an application within the scope of the UK business school website. Analysis of the collected data led to the deletion of one question item. As a result of the research, the remaining 23 questions were grouped into four main dimensions: ease of use, experience, information, communication, and integration (Barnes and Vidgen, 2000). The results of that research show the quality of WebQual 1.0 so that it raises the quality of website information in WebQual 2.0. However, in the implementation of WebQual, on a Business to Consumer (B2C) website, it is clear that the interaction quality perspective is not well represented in WebQual 1.0. Regarding service quality, especially the SERVQUAL model, it is used to improve the information quality aspect of WebQual with interaction quality.

The development of WebQual from version 1.0 to 2.0 required significant changes to existing instruments and queries. After the analysis of the SERVQUAL instrument resulted in the identification of redundant questions. Most of the critical questions in the SERVQUAL model did not match WebQual 2.0, so the number of indicators with 24 questions was maintained. There are some advantages and disadvantages in this version where WebQual 1.0 is very important in terms of information quality but less strong in terms of service interaction. Likewise, WebQual 2.0, which emphasizes the quality of interaction, removes some of the information quality from WebQual 1.0. After that came WebQual 3.0, where WebQual 3.0 leads to identifying three dimensions of website quality: usability, information quality, and service interaction quality. After several evaluations, the Webqual model was developed, which made Webqual 4.0 appear

The subsequent development in WebQual version 4.0 emphasizes more on users and perceptions than website designers. Webqual 4.0 is an extension of the previous version of Webqual. On implementation, WebQual 4.0 is used to estimate the quality of a commercial website (Giyanti and Suparti, 2018). The dimensions of Webqual 4.0 emphasize three research areas, namely:

1. Information Quality (IQ): The quality of information includes accurate information, reliable information, up-to-date information, information following the topic of discussion, ease of information to understand, detailed information, and information presented in an appropriate design format.

2. Service Interaction Quality (IN): Service interaction quality is about experienced by users when they delve deeper into the site, manifested by trust and empathy, facilitates communication, creates a more personal emotional feeling, has confidence in providing personal information, can make a specific community.

3. Usability (US): a quality related to site design, for example, appearance, convenience usage, navigation, and presentation presented to the user. 
The three research areas will measure user satisfaction. The WebQual 4.0 model used in this research is a theory development (Barnes and Vidgen, 2005). Based on this model, this research has the hypotheses :

- H1: Usability (US) has a positive impact on User Satisfaction (USS)

- H2: Information Quality (IQ) has a positive impact on User Satisfaction (USS)

- H3: Service Interaction Quality (IN) has a positive impact effect on User Satisfaction(USS)

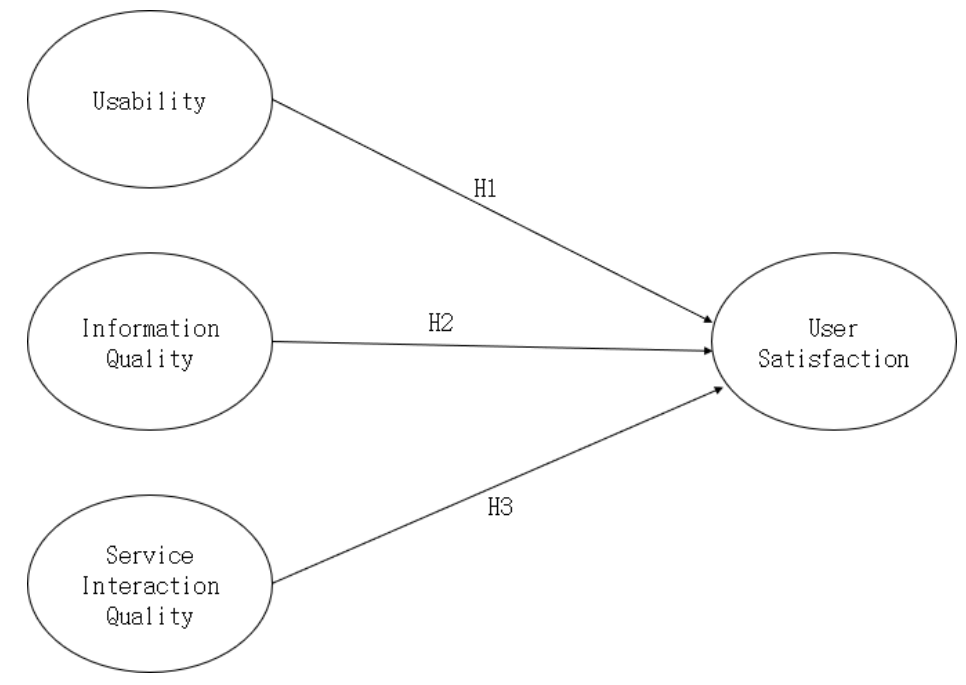

Figure 1. WebQual 4.0 Model

\section{RESEARCH METHOD}

Data collection was carried out for one month in mid-2021. WAG members of the UPN "Veteran" Yogyakarta cooperative were used as samples. The questionnaires were distributed online, and 163 questionnaires were returned, but 13 were unable to be used due to missing data, so that this research used 150 questionnaires for analysis. The research questionnaire was designed based on the dependent and independent variable indicators as mention in Literature Review in the early part. The Likert scale is used in questions where the Likert scale measures a person's opinions and perceptions about social phenomena. The variables to be measured are translated into indicator variables, arranged into items (Tulodo, 2019).

A quantitative approach is used in this research with use SPPS version 23 to carry out the analysis. Different studies were conducted in sequence to answer the research objectives and test the hypotheses mentioned in the literature review, including reliability and validity analysis, correlation analysis, and regression analysis.

The model approach used in this research uses Webqual 4.0. Instruments of question derived from information quality, service interaction quality, usability, and user satisfaction variables whose detailed explanations can be seen in table 1. 
RSF Conference Series: Engineering and Technology

Vol 1 (1), 603-608

A Measuring Satisfaction of Member UPN "Veteran" Yogyakarta Cooperative Whatsapp Group: Webqual 4.0

Model Adoption

Sriyono, Oliver Samuel Simanjuntak, Riza Prapascatama Agusdin, Sylvert Prian Tahalea

Table 1 Variables and Indicators on WebQual 4.0

\begin{tabular}{|c|c|}
\hline Variable Names & Indicator \\
\hline \multirow{4}{*}{ USABILITY } & Easy to learn and operate \\
\cline { 2 - 2 } & Easy to understand \\
\cline { 2 - 2 } & Easy to navigate \\
\cline { 2 - 2 } & Easy to use \\
\cline { 2 - 2 } & Attractive appearance \\
\cline { 2 - 2 } & Appropriate to the type of site \\
\cline { 2 - 2 } & Conveys a sense of competency \\
\hline \multirow{4}{*}{ QUALITY } & Positive experience \\
\cline { 2 - 2 } & Give accurate information \\
\cline { 2 - 2 } & Give reliable information \\
\cline { 2 - 2 } & Give timely information \\
\cline { 2 - 2 } & Give relevant information \\
\cline { 2 - 2 } & Easy to understand \\
\cline { 2 - 2 } INFORMATION & Information at the right level of \\
INTERACTION & detail \\
\hline INTERACTION & Information in an appropriate \\
& format \\
\cline { 2 - 2 } & Have a good reputation \\
\cline { 2 - 2 } & Information feels secure \\
\cline { 2 - 2 } & Sense of personalization \\
\hline USER SATISFACTION & Sense of community \\
\hline \multirow{4}{*}{ INITY/SERVICE } & Communicate with the \\
& organization \\
\hline
\end{tabular}

\section{FINDING AND DISCUSSION}

It was found that there were more male (54.4\%) than female (45.6\%) respondents with an average age composition above 40 years (66\%) which could be considered middle-aged. Respondents were people from UPN "Veteran" Yogyakarta, which consisted of Lecturers (32.9\%) and Education Staff Personnel (22.1\%). The rest were members from outside UPN "Veterans" Yogyakarta with various professions such as private employees, teachers, civil servants, and self-employed. Another fact is that the majority of respondents (51.7\%) have incomes between Rp. 2,500,000 - Rp. 5,000,000 per month.

The validity and reliability tests were carried out using SPSS version 23 . Each variable passed the validity test and reliability test, the value of Cronbach alpha each variable showing above 0.6 , which means the data has passed the reliability test. The data can be said to be reliable.

After passing the validity and reliability tests, correlation and regression analysis were carried out. This analysis aims to determine the relationship between each variable and test hypotheses made previously. First, three hypotheses are tested using correlation analysis techniques. The results obtained after conducting correlation analysis are:

- H1, which proposed Usability (US) has a positive impact on User Satisfaction (USS). This hypothesis is not accepted because the significant value $>0.05$ and Pearson correlation are below the standard.

- H2, which proposed Information Quality (IQ) has a positive impact on User Satisfaction (USS). This hypothesis is not accepted because the significant value $>0.05$ and Pearson correlation is below the standard 
- H3, which proposed Service Interaction Quality (IN) has a positive impact on User Satisfaction (USS). This hypothesis is accepted because the significant value $<0.05$ and Pearson correlation is above the standard.

Table 2 Correlation Results

\begin{tabular}{|l|c|c|c|c|c|}
\hline \multirow{2}{*}{ Hypothesis } & \multirow{2}{*}{ Variables } & \multirow{2}{*}{ Technique } & \multicolumn{2}{|c|}{ Findings } & \multirow{2}{*}{ Results } \\
\cline { 4 - 6 } & & Significant & $\begin{array}{l}\text { Pearson } \\
\text { Correlation }\end{array}$ & \\
\hline H1 & US - USS & Correlation & 0.067 & 0.150 & Not Accepted \\
\hline H2 & IQ - USS & Correlation & 0.113 & 0.130 & Not Accepted \\
\hline H3 & IN - USS & Correlation & 0.002 & 0.255 & Accepted \\
\hline
\end{tabular}

There are limitations in correlation analysis. Therefore it is done a regression analysis was carried out to retest the three hypotheses. The results obtained after performing a regression analysis are the value of the coefficient of multiple determination or can be referred to as $R^{2}$ of 0.080 , which means that $8 \%$ of the variance of User Satisfaction (USS) can be explained by the three independent variables (information quality, service interaction quality, usability). The remaining $92 \%$ of user satisfaction is driven by other unknown variables or variables not mentioned in this research. The results explanation of each hypothesis are :

- H1, which proposed Usability (US) has a positive impact on User Satisfaction (USS). This hypothesis is not accepted because the significant value is $>0.05$, and the beta value indicates (-).

- H2, which proposed Information Quality (IQ) has a positive impact on User Satisfaction (USS). This hypothesis is not accepted because the significant value is $>0.05$, and the beta value indicates $(-)$.

- H3, which proposed Service Interaction Quality (IN) has a positive impact on User Satisfaction (USS). This hypothesis is accepted because the significant value is $<0.05$, and the beta value indicates $(+)$.

Table 3 Regression Results

\begin{tabular}{|c|c|c|c|c|c|}
\hline \multirow{2}{*}{ Hypothesis } & \multirow{2}{*}{ Variables } & \multirow{2}{*}{ Technique } & \multicolumn{2}{|c|}{ Findings } & \multirow{2}{*}{ Results } \\
\cline { 4 - 5 } & & & Significant & & \\
\hline H1 & US - USS & Regression & 0.320 & -.0153 & Not Accepted \\
\hline H2 & IQ - USS & Regression & 0.472 & -0.094 & Not Accepted \\
\hline H3 & IN - USS & Regression & 0.003 & 0.453 & Accepted \\
\hline
\end{tabular}

This research adopts the Webqual 4.0 model to measure the satisfaction of members in the WAG Cooperative UPN "Veteran" Yogyakarta. The results of the analysis Service Interaction Quality has a positive effect on User Satisfaction, proving that the cooperative's service to members in WAG is felicitous. Members consider WAG Koperasi UPN "Veteran" Yogyakarta as a safe place to provide their personal information, exchange information, and interact with other members or with the management of the cooperative. With the WAG, the cooperative also makes it easier for cooperative members to interact (ask a question, complain, or provide suggestions) with the management of the cooperative.

In addition, there are analysis results that indicate no positive relationship between Information Quality and Usability to User Satisfaction. It proves the quality of the information provided in the Cooperative WAG is patchy. It meant the information provided is not easy to understand, lacks updates or the information provided is not detailed. Members of the WAG find it challenging to look for information that has long been provided on WAG because the information has been covered with the latest messages or if the sender of the message has deleted the file that has been sent previously on the WAG, the file will also disappear in the WAG so that members must do download the file if they do not want the information to be lost. 


\section{CONCLUSION AND FURTHER RESEARCH}

This research measures the satisfaction of WAG members of the UPN "Veteran" Yogyakarta Cooperative by adopting the Webqual 4.0 model gives the following results:

1. The Webqual 4.0 model is sufficient to provide insight regarding the satisfaction of the WAG Cooperative members of the UPN "Veteran" Yogyakarta so that it can provide suggestions for improving the cooperative management

2. Members of the WAG Cooperative UPN "Veteran" Yogyakarta are satisfied with the Service Interaction provided in the WAG and dissatisfied with the quality of the information provided in the WAG and the use of WAG in the media to provide information so that the management needs to offer different media to provide information that is more accessible, easy used and the information provided is not easily lost on the press.

Although this research has been able to achieve the purpose of this research, the limitations need to be surmounted. First, the model approach used for measurement only uses three variables. It is necessary to look for an approach model with more variables to be explored more. Second, respondents are not equally represented. Judging from the demographic results of the respondents, many of them are from the internal circle of UPN "Veteran" Yogyakarta, even though the cooperative members are not only from inner circles. Future research should expand the distribution of the questionnaire to areas outside UPN "Veteran" Yogyakarta area. In addition, it should also be extended to other age groups.

\section{Acknowledgement}

The author would like to thank the research institutes and community service in Universitas Pembangunan Nasional Veteran Yogyakarta, Indonesia, which has provided funding for this research.

\section{REFERENCES}

Barnes, S. J. and Vidgen, R. T. (2005) 'Data triangulation in action: Using comment analysis to refine web quality metrics', in Proceedings of the 13th European Conference on Information Systems, Information Systems in a Rapidly Changing Economy, ECIS 2005.

Barnes, S. and Vidgen, R. (2000) 'WebQual : An Exploration of Web-site Quality', Communications.

Diana, D. and Veronika, N. D. M. (2018) 'ANALISIS KUALITAS WEBSITE PROVINSI BENGKULU MENGGUNAKAN METODE WEBQUAL 4.0', Pseudocode. doi: 10.33369/pseudocode.5.1.10-17.

Giyanti, I. and Suparti, E. (2018) 'PENILAIAN KUALITAS APLIKASI HALAL MUI DENGAN WEBQUAL 4.0 DAN PENGARUHNYA TERHADAP KEPUTUSAN PENGGUNAAN', J@ti Undip :Jurnal Teknik Industri. doi: 10.14710/jati.13.2.91-98.

Hermanto, A., Supangat, S. and Mandita, F. (2017) 'Evaluasi Usabilitas Layanan Sistem Informasi Akademik Berdasarkan Kombinasi ServQual dan Webqual Studi Kasus : SIAKAD Politeknik XYZ', Journal of Information Systems Engineering and Business Intelligence. doi: 10.20473/jisebi.3.1.3339.

Johnston, M. J. et al. (2015) 'Smartphones let surgeons know WhatsApp: An analysis of communication in emergency surgical teams', American Journal of Surgery. doi:10.1016/j.amjsurg.2014.08.030.

Mortensen, C. D. [Ed] (2008) 'Communication theory (2nd ed.).', Communication theory (2nd ed.).

Ngulum, M. C. and Aries, D. I. (2020) 'Evaluasi Kualitas Website Simontasi Unesa Menggunakan Metode Webqual Dan Importance Performance Analysis (Ipa)', Journal of Informatics and Computer Science (JINACS).

Rambe, P. and Chipunza, C. (2013) 'Using mobile devices to leverage student access to collaborativelygenerated resources: A case of WhatsApp instant messaging at a South African University', in. doi: 10.2991/icaicte.2013.66.

Tulodo, B. A. R. (2019) 'Analisis Pengaruh Kualitas Sistem, Kualitas Informasi dan Perceived Usefulness terhadap Kepuasan Pengguna Aplikasi Care dalam Upaya Peningkatan Kinerja Karyawan (Studi Kasus PT. Malacca Trust Wuwungan Insurance, Tbk.)', Jurnal Riset Manajemen Sains Indonesia (JRMSI). 